\title{
A POSSIBLE ROLE OF THE CHOLINERGIC AND PURINERGIC RECEPTOR INTERACTION IN THE REGULATION OF THE RAT URINARY BLADDER FUNCTION
}

by

Ágnes Jenes M.D.

Ferenc Ruzsnavszky M.D.

Andrea Telek M.D./Ph.D.

Gyula P Szigeti M.D./Ph.D.

and

László Csernoch Ph.D.

from

Department of Physiology, Medical and Health Science Center, University of Debrecen, Debrecen, Hungary

Corresponding author:

László Csernoch Ph.D.

Department of Physiology

Medical and Health Science Center

University of Debrecen

Nagyerdei krt. 98.

PO.Box. 22

Debrecen

Hungary

Phone: 36-52-416-634

FAX: 36-52-432-289

e-mail: csl@phys.dote.hu 


\begin{abstract}
Under pathological conditions the shortening of the upper (dome) and lower (base) parts of the urinary bladder are different. Namely, the contraction of the base is milder than that of the dome. To understand how different parts of the urinary bladder could respond differently to the same stimulation, the cellular mechanisms that might be responsible for cholinergic effects blocking non-adrenergic non-cholinergic contractions in the rat urinary bladder were investigated. Rat urinary bladder smooth muscle cells were thus freshly isolated or cultured and the contribution from cholinergic and purinergic pathways to their $\mathrm{Ca}^{2+}$ homeostasis together with the expression of nicotinic (nAChR) and purinergic receptors was examined. The ATP-evoked $\mathrm{Ca}^{2+}$ transients in rat smooth muscle cells did not show any desensitization. However, when ATP was administered together with carbamylcholine (CCh), the latter essentially prevented ATP from evoking $\mathrm{Ca}^{2+}$ transients in smooth muscle cells from the base (suppression to $12 \pm 2.5 \%$ of control, $n=57 ; \mathrm{p}<0.01)$, but not from the dome $(99 \pm 5 \%$ of control, $n=52 ; \mathrm{p}>0.05)$ of the rat urinary bladder. While atropine was unable to modify $(6 \pm 3 \%$ of control, $n=14 ; \mathrm{p}<0.05)$, $\alpha$-bungarotoxin $(118 \pm 12 \%$ of control, $n=20 ; p>0.05)$ blocked the inhibitory effects of CCh. Additionally, $\alpha 7$ subunits of nAChR were identified using immunocytochemistry, immunohistochemistry, and Western blot in cultured urinary bladder smooth muscle cells, in urinary bladder sections, and in urinary bladder muscle strips, respectively, suggesting that the activation of nAChR modifies the action of ATP.
\end{abstract}

Keywords

non-adrenergic, non-cholinergic contractions; nicotinic acetylcholine receptors; purinergic receptors; receptor interaction; urinary bladder smooth muscle

Short title

Cholinergic-purinergic receptor interaction in rat bladder smooth muscle 


\section{Introduction}

The function of the urinary bladder is to relax and store urine during filling, and contract to empty the bladder during micturition. These roles are achieved through complex interactions between the autonomic nervous system and the urinary bladder, primarily the smooth muscle cells. Urinary bladder smooth muscle in adult rats is well innervated (Gabella, 1999). The bundles of nerve fibres branch repeatedly in urinary bladder smooth muscle and eventually become single fibres containing varicosities. The varicosities contain neurotransmitters, including acetylcholine (ACh) and adenosine triphosphate (ATP) (Gabella, 1995).

During electrical stimulation of the parasympathic nerves ACh and ATP are co-released from the nerve terminals to stimulate the muscarinic and purinergic receptors of the smooth muscle cells, respectively, and to elicit bladder contraction (Dowdall et al. 1974; Kasakov and Burnstock, 1982; Theobald and de Groat, 1989). Acetylcholine is a ubiquitous transmitter, while ATP plays an additional role in many species, including rats (Calvert et al. 2001; Somogyi et al. 2002; Szigeti et al. 2005). Acetylcholine acts via $\mathrm{M}_{3}$ receptor activation, generation of intracellular inositol-1,4,5-trisphosphate $\left(\mathrm{IP}_{3}\right)$ and $\mathrm{Ca}^{2+}$ release from intracellular stores. There is also evidence that muscarinic activation leads to $\mathrm{Ca}^{2+}$ influx (Schneider et al., 2004). Conversely, ATP binds to ionotropic $\mathrm{P} 2 \mathrm{X}$ receptors, depolarizing the cell membrane and instigating $\mathrm{Ca}^{2+}$ influx through voltage-activated (mainly L-type) $\mathrm{Ca}^{2+}$ channels (Andersson and Arner, 2004). The $\mathrm{Ca}^{2+}$ influx could initiate $\mathrm{Ca}^{2+}$-induced $\mathrm{Ca}^{2+}$ release from intracellular stores and lead to contractile protein activation. Thus, modulation of intracellular calcium concentration $\left(\left[\mathrm{Ca}^{2+}\right]_{\mathrm{i}}\right)$ remains a common pathway to regulate detrusor contractility, with additional modulation via alterations to the $\mathrm{Ca}^{2+}$ sensitivity of contractile proteins (Andersson and Arner, 2004; Arner et al. 2007).

Transient increases in $\left[\mathrm{Ca}^{2+}\right]_{\mathrm{i}}$ in smooth muscle have been recorded following the activation of purinergic receptors. In urinary bladder smooth muscle, the activation of purinergic receptors may induce excitatory junctional potentials and $\mathrm{Ca}^{2+}$ transients (Bramich and Brading, 1996; Hashitani et al. 2000). Field stimulation of the smooth muscle evoked local, transient $\mathrm{Ca}^{2+}$ release events. These events were mediated by postsynaptic smooth muscle $\mathrm{P} 2 \mathrm{X}$ receptors activated by ATP released from synaptic varicosities (Brain et al. 2002, 2003). Pharmacological studies also confirmed that junctional $\mathrm{Ca}^{2+}$ transients were mediated through the activation of purinergic receptors (Lamont and Wier, 2002; Lamont et al. 2003). 
Ligand-gated receptors may interact and regulate one other both at the neuronal and the end-organ levels and modulate their responses to external stimuli (Searl and Silinsky, 1998). G-protein coupled metabotropic receptors commonly "cross-talk" through intracellular second messenger molecules and protein phosphorylation (de Blasi et al., 2001; Moldrich and Beart, 2003). Recently, ionotropic receptors have also been shown to interact directly with one another in ganglia. Co-activation of the nicotinic and the $\mathrm{P} 2 \mathrm{X}_{2}$ purinergic receptors inhibited the functions of both ion-channel receptors through direct protein-protein interaction on the neuronal cell membrane (Nakazawa, 1994; Searl et al., 1998; Zhou and Galligan, 1998; Barajas-Lopez et al., 1998; Khakh et al., 2000, 2005). Negative interactions between the nicotinic and 5- $\mathrm{HT}_{3}$ receptors (Barajas-Lopez et al., 2002; Boue-Grabot et al., 2003) and between the $\mathrm{GABA}_{\mathrm{A}}$ and P2X purinergic receptors (Sokolova et al., 2001) have also been described when the two ionotropic receptors were co-activated in neurons. However, similar interaction between nicotinic and purinergic receptors at the bladder smooth muscle level has not been described on cellular but suggested at tissue level (Lai et al. 2008).

Here we investigated the cholinergic and purinergic contribution to the $\mathrm{Ca}^{2+}$ homeostasis of smooth muscle cells isolated from young adult rat urinary bladders. Given the potential role for nicotinic acetylcholine receptors (nAChRs) in the neural control of bladder function, the current study was aimed to determine whether nAChRs are also expressed in the smooth muscle cells and whether activation of these receptors can alter the function of these cells. We present evidence for the existence and determine its location dependence of the interaction between the purinergic and cholinergic signaling in smooth muscle cells of the urinary bladder. Certain aspects of these results were presented at the Annual Conference of the European Muscle Society (Jenes et al. 2006; Szigeti et al, 2007). 


\section{Materials and Methods}

All experiments were performed in accordance with Hungarian guidelines and were in compliance with the "European Convention for the Protection of Vertebrate Animals used for Experimental and other Scientific Purposes" (Council of Europe No 123, Strasbourg 1985).

\section{Smooth muscle cell culture from rat urinary bladder}

Young adult Wistar rats (male and female, 8-12 weeks old) were terminally anaesthetized by isoflurane, bladders were removed, opened and cut into a base and a dome part. The pieces were placed into Hank's solution and the urothelial layer was peeled off. Each smooth muscle piece was placed into $5 \mathrm{ml} 0.75 \mathrm{mg} \mathrm{ml}-1$ trypsin (Sigma-Aldrich, Heidelberg, Germany)-0.4 mg ml-1 EDTA (Sigma-Aldrich, Heidelberg, Germany) solution, and incubated in a shaking bath for 30 minutes at $37{ }^{\circ} \mathrm{C}$. After transferring into RPMI 1640 (Roswell Park Memorial Institute) solution containing $0.75 \mathrm{mg}$ ml-1 collagenase (Sigma-Aldrich, Heidelberg, Germany) the smooth muscle was cut into small pieces and incubated in shaking bath for further 45 minutes at $37{ }^{\circ} \mathrm{C}$. After incubation $2 \mathrm{ml}$ fetal bovine serum (FBS) was added, cells were centrifuged at 1000 RPM for 10 minutes, then the superfusate containing collagenase was removed. Cells were resuspended in $3 \mathrm{ml}$ RPMI solution containing 10\% FBS and centrifuged again at 1000 RPM for 10 minutes (twice). After the last cleaning process $3 \mathrm{ml}$ RPMI solution containing 10\% FBS was added for 3 plates (diameter $3 \mathrm{~cm}$ ) having $1 \mathrm{ml}$ cell suspension each. This medium was renewed every second day until the cells reached a confluence of $60-70 \%$. At that point, the FBS content of the RPMI medium was reduced to $1 \%$ for 2-3 more days to facilitate myocyte differentiation. Experiments were carried out on 5-7-days-old cultures.

The smooth muscle cells in the cultures were morphologically distinct from the interstitial cells and their identity were confirmed with immunocytochemistry using primary antibodies against alpha smooth muscle actin.

\section{Freshly isolated smooth muscle cells from rat urinary bladder}

Same method was used as for the cell culture, but the isolated cells were tested right after they attached to the coverslips. All of these experiments were carried out within 20 hours after removing the urinary bladder from the rats. 
Fluorescent measurement of $\left[\mathrm{Ca}^{2+}\right]_{i}$

Changes in the concentration of $\left[\mathrm{Ca}^{2+}\right]_{i}$ were detected using the fluorescent dye Fura-2 as described in our previous reports (Bíró et al., 1998; Csernoch et al., 2000). To introduce the calcium-sensitive probe into the intracellular space cells were incubated for $90 \mathrm{~min}$ at $37^{\circ} \mathrm{C}$ with $15 \mu \mathrm{M}$ Fura-2 AM (Molecular Probes, Eugene, OR, USA). Coverslips were then washed with normal HEPES Tyrode's solution (in mM: $137 \mathrm{NaCl}, 5.4 \mathrm{KCl}, 0.5 \mathrm{MgCl}_{2}$, $1.8 \mathrm{CaCl}_{2}, 11.8 \mathrm{HEPES}-\mathrm{NaOH}, 1 \mathrm{~g} \mathrm{l}-1$ glucose, $\mathrm{pH}$ 7.4) and this solution also provided the extracellular environment for the cells throughout the entire measurement. The coverslips with the Fura-2 loaded cells were then placed on the stage of an inverted fluorescence microscope (Diaphot, Nikon, Japan). The measuring bath was constantly perfused with normal HEPES Tyrode's solution at a $2 \mathrm{ml} \mathrm{min-1}$ rate (Econo Pump, Bio-Rad Hungary, Budapest, Hungary). Test solutions were directly applied to the cells through a local perfusion capillary (Perfusion Pencil $^{\mathrm{TM}}$, AutoMate Scientific, San Francisco, CA, USA) with an internal diameter of $250 \mu \mathrm{m}$ at a $1.5 \mu \mathrm{s}-1$ rate, using a local perfusion system (Valve $\operatorname{Bank}^{\mathrm{TM}} 8$ version 2.0, AutoMate Scientific, San Francisco, CA, USA). Experiments were performed at room temperature $\left(22-24^{\circ} \mathrm{C}\right)$. Excitation wavelength was altered between 340 and $380 \mathrm{~nm}$ by a dual-wavelength monochromator and an on-line connected microcomputer (Deltascan, Photon Technology International, New Brunswick, NJ, USA) while the emission was monitored at $510 \mathrm{~nm}$ using a photomultiplier at an acquisition rate of $10 \mathrm{~Hz}$ per ratio. Background fluorescence was measured at cell-free regions of the coverslip and subtracted automatically.

$\left[\mathrm{Ca}^{2+}\right]_{\mathrm{i}}$ levels were calculated according to the method of Grynkiewicz et al. (1985) from the ratio $\left(R=F_{340} / F_{380}\right)$ of the fluorescence intensities measured with excitation wavelengths $340 \mathrm{~nm}\left(F_{340}\right)$ and $380 \mathrm{~nm}\left(F_{380}\right)$ as previously described (Bíró et al., 1998; Csernoch et al., 2000) using in vivo calibration data.

\section{Immunocytochemistry}

Smooth muscle cells from urinary bladders were cultured on sterile plates. The 5-7 days old cells were fixed in acetone for $5 \mathrm{~min}$ and then permeabilized by $0.1 \%$ Triton-X-100 (Sigma-Aldrich, Heidelberg, Germany) in a phosphate buffered saline (PBS, $0.02 \mathrm{M} \mathrm{NaH}_{2} \mathrm{PO}_{4}, 0.1 \mathrm{M} \mathrm{NaCl}$ ) for $10 \mathrm{~min}$. After washing with PBS solution and blocking with $1 \%$ bovine serum albumin (BSA, Sigma-Aldrich, Heidelberg, Germany) in PBS for 30 min, cells were incubated with anti-nAChR $\alpha 7$ primary antibodies (Santa Cruz Biotechnology, Santa Cruz, CA, USA) or anti- 
$\mathrm{P} 2 \mathrm{X}_{2}$ receptor primary antibodies (Santa Cruz Biotechnology, Santa Cruz, CA, USA) overnight at $4{ }^{\circ} \mathrm{C}$ (dilution 1:50, 1:200, 1:500). Plates were washed three times in PBS then incubated with fluoresceine isothiocyanate (FITC) conjugated secondary antibodies (Vector Laboratories, Burlingame, CA, USA) for 45 min (dilution 1:200). The nuclei of cells were visualised using 4',6-diamidino-2-phenylindole (DAPI). Cells were examined on a confocal microscope (Zeiss LSM 510 META, Zeiss, Oberkochen, Germany).

\section{Immunohistochemistry}

The tissue specimens were immediately fixed in $4 \%$ buffered formaldehyde $(24 \mathrm{~h})$, embedded in paraffin wax, and $4 \mu \mathrm{m}$ thick sections were cut. The endogenous peroxidase activity was blocked with $3 \% \mathrm{H}_{2} \mathrm{O}_{2}$ in methanol (10 min, room temperature). Non-specific binding was prevented by incubating the sections with BSA. The tissue sections were then incubated overnight at $4{ }^{\circ} \mathrm{C}$ with anti-nAChR $\alpha$-specific primary antibodies (dilution 1:200, Santa Cruz Biotechnology). After incubation, the slices were rinsed three times with PBS for 5 minutes. The sections were incubated in biotinylated anti-goat secondary antibodies (raised in rabbit) for 30 min (1:100, Dako, Glostrup, Denmark), then rinsed with PBS and incubated with horseradish peroxidase-conjugated streptavidin (30 $\min ; 1: 500$; room temperature). In these instances visualisation of the immunolabelling was also achieved using 3,3'-diaminobenzidine (DAB). At the end of the procedure slight counterstaining was performed using hematoxylin. Control experiments were regularly performed. In these cases, the sections were incubated overnight without the primary antibody.

\section{Western blot}

To determine the expression of $\mathrm{nAChR} \alpha 7$ subunits in different parts of the young adult rat bladder, Western blot technique was applied. Tissues were homogenized in homogenization buffer [20 mM Tris-Cl, pH 7.4, 5 mM EGTA, $1 \mathrm{mM}$ 4-(2-aminoethyl)benzenesulfonyl fluoride, $20 \mu \mathrm{M}$ leupeptin, all from Sigma] and the protein content of samples was measured by a modified bicinchoninic acid (BCA) protein assay (Pierce, Rockford, IL, USA). The samples were subjected to sodium dodecyl sulfate-polyacrylamide gel electrophoresis ( $8 \%$ gels were loaded with 20 to $30 \mu \mathrm{g}$ protein per lane), transferred to nitrocellulose membranes (Bio-Rad, Vienna, Austria), and then probed with the above mentioned anti-nAChR $\alpha 7$ antibodies (1:100). A horseradish peroxidase-conjugated rabbit anti-goat IgG antibody (1:500, Bio-Rad) was used as a secondary antibody, and the immunoreactive bands were visualized by 
enhanced chemiluminescence (Gel Logic 1500 Imaging System, Carestream, Rochester, NY, USA). Western blotting experiments were repeated five separate times, and the protein bands were analyzed by Image $\mathbf{J}$ software provided by the NIH. The densitometric values were normalized to the values of actin immunoreactivity to correct any loading and transfer differences between samples.

\section{Data analysis}

Data were analyzed using Microsoft Excel $^{\circledR}$ (Microsoft, Redmond, WA, USA) and Microcal Origin ${ }^{\circledR}$ (OriginLab, MA, USA) computer softwares. Data are expressed as mean \pm SEM. Student's t-test was used to compare paired data between the control group (first ATP application) and the other groups (purinergic and cholinergic agonists and antagonists), and 2-tailed $\mathrm{p}<0.05$ was taken to indicate statistical significance. 


\section{Results}

Effect of repetitive ATP application on the $\mathrm{Ca}^{2+}$ transients of cultured smooth muscle cells from the urinary bladder

To study the role of the purinergic and cholinergic stimulation, first the shape and reproducibility of the ATP-induced $\mathrm{Ca}^{2+}$ transients were determined on cultured rat urinary bladder smooth muscle cells (Fig. 1). ATP $(180 \mu \mathrm{M})$ was applied for 40 seconds three times (at time zero, then three and six minutes later) to activate P2 receptors and induce $\mathrm{Ca}^{2+}$ transients. There were no visible changes in the second and third $\mathrm{Ca}^{2+}$ transients as compared to the first one (Fig. 1A). To quantify any possible changes that might have occurred, single exponential functions were fitted to the declining phase of the calcium transients and their time constant $(\tau)$ was determined. In addition, the peak of the first time derivative of the signal was used to assess its maximal rate-of-rise. Pooled data from 7 independent experiments ( 7 cells from 7 animals) confirmed that the amplitude (Fig. 1B), the $\tau$ (Fig. 1C) and the maximal rate-of-rise (Fig. 1D) of the second and third transients were not significantly different statistically $(p>0.05)$ from those of the first transient.

Interaction between purinergic and cholinergic pathways at the level of the $\mathrm{Ca}^{2+}$ transients on freshly isolated and cultured smooth muscle cells

To understand the possible cross-reactivity between the purinergic and cholinergic signaling pathways, cultured and freshly isolated smooth muscle cells from adult rat urinary bladders were stimulated by the agonists of the two pathways (Fig. 2). While ATP was essentially always (more than $90 \%$ of the cells) capable of initiating a calcium transient, the parasympathetic agonists carbamylcholine (carbachol; $\mathrm{CCh}$ ) and nicotine (nic) could not induce elevations in $\left[\mathrm{Ca}^{2+}\right]_{i}$ in rat smooth muscle cells, either cultured $(\mathrm{n}=109)$ or freshly isolated $(\mathrm{n}=5)$.

However, when ATP was administered together with $10 \mu \mathrm{M} \mathrm{CCh}, \mathrm{CCh}$ prevented ATP from evoking $\mathrm{Ca}^{2+}$ transients in the rat smooth muscle cell from the base of the urinary bladder (Fig. 2B, 2C). All together 57 cultured (Fig. 2B) and 3 freshly isolated (Fig. 2C) cells from the base of the urinary bladder prepared from 18 and 3, respectively animals were tested. While $\mathrm{CCh}$ decreased the amplitude of the ATP-evoked $\mathrm{Ca}^{2+}$ transients by $88 \pm 2.5 \%$ ( $\mathrm{p}<0.01$ ), this cross-inhibition was not present when ATP was applied together with $5 \mu \mathrm{M}$ nicotine (Fig. 2). The effect of nicotine was tested on 20 cells obtained from 6 animals. On the other hand, neither carbachol nor 
nicotine inhibited the effect of ATP in the cells of the dome of the urinary bladder (52 cells prepared from 16 rats, Fig. 2A).

\section{Pharmacological characterization of the cross-inhibition}

To establish the cholinergic receptor subtype responsible for the observed cross-inhibition in the cells of the base of the urinary bladders, muscarinic and nicotinic antagonists were applied (Fig. 3). The muscarinic receptor blocker atropine (1 $\mu \mathrm{M}$; Fig. 3A, 3B) was unable to modify the purinergic-cholinergic interactions (24 cells from 4 animals). That is, on the one hand, when the cross-inhibition was present for ATP and $\mathrm{CCh}$ - on cells from the base -, the co-application of atropine with ATP and CCh could not prevent the purinergic-cholinergic inhibition (Fig. 3A, 4). On the other hand, when there was no interaction between the purinergic and cholinergic pathways without atropine - on cells from the dome -, there was no interaction between them in the presence of atropine either (Fig. 3B, 4).

In contrast, the presence of $\alpha$-bungarotoxin - a specific competitive antagonist of the nicotinic acetylcholine receptor $(\mathrm{nAChR})$ - prevented carbachol from interfering with the ATP-evoked calcium transients (Fig. 3C, 3D, 4). In 20 cells from 3 animals isolated from the base of urinary bladders CCh was unable to block the effect of ATP when $\alpha$-bungarotoxin (500 nM) was present in the bathing medium (Fig. 3C, 4). Nevertheless, $\alpha$ bungarotoxin did not interfere with the ATP-evoked signals since the simultaneous presence of $\mathrm{CCh}$ and the toxin did not modify the calcium transients in the cells isolated from the dome (Fig. 4D). The pooled data (Fig. 4) confirmed that while the effect of $\alpha$-bungarotoxin was statistically significant $(\mathrm{p}<0.05)$ in cells from the base, the toxin did not modify significantly $(\mathrm{p}>0.05)$ the changes in $\left[\mathrm{Ca}^{2+}\right]_{\mathrm{i}}$ in cells from the dome.

To narrow the possible receptor candidates for the purinergic pathway different purinergic agonists were also tested. From the P2X receptor agonists neither $\alpha, \beta$-methylene-ATP $(10 \mu \mathrm{M}$; cultures from 6 animals, data from 25 cells, 13 cells from the base and 12 cells from the dome), nor 2-methyl-tio-ATP (180 $\mu \mathrm{M}$; cultures from 3 animals, data from 7 cells, 4 cells from the base and 3 cells from the dome) induced any elevation in $\left[\mathrm{Ca}^{2+}\right]_{\mathrm{i}}$ (Fig. 5A). In this respect, there were no significant differences between the cells isolated from the base and the dome. In addition, the P2Y receptor agonist UTP $(180 \mu \mathrm{M}$; cultures from 5 animals, data from 29 cells, 20 cells from the base and 9 cells from the dome) could not induce $\mathrm{Ca}^{2+}$ transients in cultured smooth muscle cells of the urinary bladder (Fig. 5B). Again, there were no significant differences, in this respect, between the cells from the 
base and the dome. In addition, the L-type calcium channel blocker nifedipine $(10 \mu \mathrm{M})$ significantly - to $38 \pm 15 \%$ of the response measured in the absence of nifedipine ( $\mathrm{p}<0.05 ; 9$ cells from 2 animals) - reduced the ATP-induced $\mathrm{Ca}^{2+}$ transients (data not shown). Noteworthy, that CCh was still able to further reduce the effect of ATP in the presence of nifedipine (to $0 \% ; 2$ cells from 1 animal).

Immunostaining of the nicotinic receptors and $P 2 X_{2}$ receptors in smooth muscle cell cultures and urinary bladder tissue sections

CCh can serve as an agonist for the $\alpha_{1}, \alpha_{3}, \alpha_{4}, \alpha_{7}$, and $\alpha_{9}$ nAChR subunits and, furthermore, it has a higher affinity than nicotine does towards the $\alpha_{1}, \alpha_{7}$, and $\alpha_{9}$ subunits (Alexander et al. 2008). This, together with the effects seen with $\alpha$-bungarotoxin (see above) led us to suspect the involvement of the $\alpha_{7}$ subunit of nAChR in the cross-inhibition detail before. To determine the distribution of the $\alpha$ subunit of the nicotinic receptors, cultured smooth muscle cells from rat urinary bladders (Fig. 6A) and bladder tissue sections (Fig. 6B) were used. Cultured smooth muscle cells from the rat urinary bladder, both from the base and from the dome, displayed $\alpha 7$ nicotinic receptor positivity, however, it seemed to be more intensive for cells from the base than that of the cells from the dome (Fig. 6A). The $\alpha 7$ nicotinic receptor immunoreactions in urinary bladder tissue sections showed similar distribution (Fig. 6B). Western-blot analysis confirmed the expression of nAChR $\alpha 7$ protein in rat urinary bladder smooth muscle strips (Fig. 6C). Furthermore, quantitative evaluation of the Western blots (normalizing the absorbance of the nAChR $\alpha 7$ band to that of the actin band) confirmed that the expression of nAChR $\alpha 7$ in the cells from the base was significantly higher than the expression in the cells from the dome (Fig. 6D, p<0.05).

Based on previous reports (Creed et al., 2010; Dutton et al., 1999; Lee et al., 2000; Studeny et al., 2005) and the pharmacological profile of the ATP-evoked calcium transients presented above, we suspected the presence of $\mathrm{P} 2 \mathrm{X}_{2}$ receptors in the rat urinary bladder smooth muscle. This was indeed confirmed using immunocytochemical and immunohistochemical surveys (Fig. 7). Distribution of the $\mathrm{P} 2 \mathrm{X}_{2}$ receptors appears to be rather cytoplasmic than membrane, which is in agreement with previous studies (). 


\section{Discussion}

This report presents evidence of purinergic-cholinergic receptor cross-inhibition in non-neural cells. This cross-inhibition between the two signaling pathways was observed in the base, but not in the dome of the rat urinary bladder.

We demonstrated the contribution of the purinergic signaling pathway to the $\mathrm{Ca}^{2+}$ homeostasis in cultured rat smooth muscle cells. ATP was able to evoke $\mathrm{Ca}^{2+}$ transients in the smooth muscle cells and these transients did not show any desensitization. When ATP was administered together with the parasympathetic agonist carbachol, the latter prevented ATP from evoking $\mathrm{Ca}^{2+}$ transients in the cells from the base of the urinary bladder. Since $\alpha$ bungarotoxin but not atropine was able to interfere with this interaction and because certain nicotinic receptors are also sensitive to $\mathrm{CCh}$, we suspected the presence of the $\mathrm{nAChR} \alpha 7$ on our cells. Smooth muscle cells from the rat urinary bladder - either isolated or in situ - displayed $\alpha 7$ nicotinic receptor positivity. Furthermore, cells from the base of the bladder seemed to have stronger immunopositivity than the cells from the dome as confirmed by Western blotting.

\section{Cholinergic and purinergic receptor activation in cultured smooth muscle cells from the urinary bladder}

Our results suggest a unique interaction between $\mathrm{P} 2 \mathrm{X}$ purinergic and a putative nicotinic receptor in the bladder smooth muscle. Earlier measurements gave evidence on cholinergic (nicotinic) and purinergic interaction between neuronal type nicotinic and $\mathrm{P} 2 \mathrm{X}_{2}$ purinergic receptors in rat sympathetic ganglia (Nakazawa, 1994), hippocampal neurons (Khakh et al., 2005), autonomic ganglia (Searl et al., 1998), and myenteric neurons (BarajasLopez et al., 1998; Zhou and Galligan, 1998; Brown and Galligan, 2003). In these systems, co-application of a nicotinic agonist (nicotine, cystine) and a purinergic agonist (ATP, $\alpha, \beta$-methyleneATP) produced lower additive response (inward currents, calcium influx) then what was expected from independent receptor stimulations.

The question then was, whether there are nicotinic receptors present on urinary bladder smooth muscle cells. Traditionally smooth muscle is not considered to be equipped with nicotinic receptors (Jensen et al. 2005). It is important to note that even if nicotinic receptors are present in the bladder smooth muscle, they are silent since nicotinic agonists do not elicit a contraction and no intramural ganglia can be found in rat bladders (Alian and 
Gabella, 1996; Somogyi and de Groat, 1992). However, expression of several isoforms of the nicotinic receptor has been demonstrated in vascular smooth muscle (Brüggmann et al., 2002). Nicotinic receptors are also found in the urothelium in urinary bladder (Beckel et al. 2006; Birder and de Groat, 2007). Our study provides evidence that while nicotinic receptors are present on the bladder smooth muscle cells, too, their activation is indeed not accompanied by an elevation in intracellular $\mathrm{Ca}^{2+}$ concentration. The current study, nevertheless, demonstrated that nicotinic receptors on the smooth muscle may play an important role in modulating the activity of the purinergic signal transduction.

Most of the experiments presented in this study were carried out on cells held in primary culture. Due to the fact that culturing could lead to alterations in receptor expression pattern or in the signaling pathways, we carried out similar experiments on freshly isolated cells, too. Since these cells responded similarly in all aspect - while carbachol was unable to generate $\mathrm{Ca}^{2+}$ transients it interfered with ATP in evoking an increase in $\left[\mathrm{Ca}^{2+}\right]_{\mathrm{i}}-$ we can conclude that the observations were not exclusively due to culturing.

The possible receptor subtype candidates for the cholinergic-purinergic receptor interaction

Based on our data on the pharmacology of the urinary bladder smooth muscle cells we suggest that the $\mathrm{P} 2 \mathrm{X}_{2}$ receptors have importance in this cholinergic-purinergic interaction. The $\mathrm{P} 2$ receptors displayed no or just a slow and partial desensitization. They were not activated by the application of $\alpha, \beta$-methylene-ATP, 2 -methyl-thioATP (data not shown) and UTP, consistent with the idea that ATP-induced $\mathrm{Ca}^{2+}$ transients are generated via activating $\mathrm{P} 2 \mathrm{X}_{2}$ receptors in the cultured urinary bladder smooth muscle cells. The presence of $\mathrm{P} 2 \mathrm{X}_{2}$ receptors on these cells has already been described (Creed et al., 2010; Dutton et al., 1999; Lee et al., 2000; Studeny et al., 2005) and were also detected through immunostaining in this study.

In our experiments the muscarinic receptor blocker atropine did not modify the purinergic-cholinergic interactions. When we found cross-inhibition applying ATP and CCh together, atropine could not prevent this interaction, in addition, when such interaction was not observed, atropine did not invoke such interaction either. These data suggest that muscarinic acethylcholine receptors do not have any role in the purinergic-cholinergic receptor cross-inhibition. On the other hand, the presence of $\alpha$-bungarotoxin prevented $\mathrm{CCh}$ from interfering with the purinergic signaling pathway on cells from the base but had no effect on cells from the dome. Since $\alpha$ bungarotoxin is considered as a specific antagonist for nAChR, especially for the $\alpha 7$ subunit (Couturier et al., 1990; 
Kempsill et al., 1999), we must assume a role of the nicotinic receptors instead. Our immunocyto- and immunohistochemistry, as well as Western-blot data confirmed the presence of nAChR $\alpha 7$ positive smooth muscle cells in cultures and in urinary bladder tissues from rat. It should be noted, however, that the muscarinic agonist carbachol had modulatory effect on the nicotinic acethylcholine receptors, while nicotine itself did not affect the inhibitory function of these receptors. Nevertheless, our results are in agreement with the findings that $\alpha_{1}, \alpha_{3}, \alpha_{4}, \alpha_{7}$, and $\alpha_{9}$ nAChRs can be activated by carbachol (Alexander et al. 2008), moreover, the affinity of the $\alpha_{1}, \alpha_{7}$, and $\alpha_{9}$ subunits to carbachol is higher than that to nicotine.

\section{The functional relevance of the nicotinic-purinergic cross-inhibition in urinary bladder}

Another observation in our study is that there is a difference in the receptor cross-inhibition between the base and the dome of the urinary bladder. Namely, the cross-inhibition is important in the base but not in the dome. In human urinary bladders, impaired contraction of the base might indicate outlet obstruction (Hirahara et al., 2006). Although there are considerable species differences in the regulation of urinary bladder contraction, the results presented here raise the interesting possibility that this difference in receptor cross-inhibition might contribute to the relatively milder contraction of the base as compared to the dome in this pathological condition. 


\section{Acknowledgements}

The authors are indebted for the excellent technical assistance from I. Kiss and R. Öri. This work was supported by grants from the Hungarian Scientific Research Found (OTKA F68393 and K75604), from the Hungarian Ministry of Health (ETT 186/2009) and from the Hungarian Ministry of Education (TÁMOP-4.2.208/2008-0019).

\section{Conflict of interest}

There are no conflicts of interest. 


\section{References}

Alexander SPH, Mathie A \& Peters JA (2008) Guide to Receptors and Channels (GRAC), Br J Pharmacol 153(2):S98-S100

Alian M \& Gabella G (1996) Decrease and disappearance of intramural neurons in the rat bladder during post-natal development. Neurosci Lett 218(2):103-106

Andersson KE \& Arner A (2004) Urinary bladder contraction and relaxation: physiology and pathophysiology. Physiol Rev 84(3):935-986

Arner A, Sjuve Scott R, Haase H, Morano I \& Uvelius B (2007) Intracellular calcium in hypertrophic smooth muscle from rat urinary bladder. Scand J Urol Nephrol 41(4):270-277

Barajas-Lopez C, Espinosa-Luna R \& Zhu Y (1998) Functional interactions between nicotinic and P2X channels in short-term cultures of guinea-pig submucosal neurons. J Physiol 513(3):671-683

Barajas-Lopez C, Montano LM \& Espinosa-Luna R (2002) Inhibitory interactions between 5-HT 3 and P2X channels in submucosal neurons. Am J Physiol Gastrointest Liver Physiol 283:G1238-G1248

Beckel JM, Kanai A, Lee SJ, de Groat WC \& Birder LA (2006) Expression of functional nicotinic acetylcholine receptors in rat urinary bladder epithelial cells. Am J Physiol Renal Physiol 290(1):F103-F110

Birder LA \& de Groat WC (2007) Mechanisms of disease: involvement of the urothelium in bladder dysfunction. Nat Clin Pract Urol 4(1):46-54. Review.

Bíró T, Szabó I, Kovács L, Hunyadi J \& Csernoch L (1998) Distinct subpopulations in HaCaT cells as revealed by the characteristics of intracellular calcium release induced by phosphoinositide-coupled agonists. Arch Dermatol Res 290: 270-276.

Boue-Grabot E, Barajas-Lopez C, Chakfe Y, Blais D, Belanger D, Emerit MB \& Seguela P (2003) Intracellular cross talk and physical interaction between two classes of neurotransmitter-gated channels. J Neurosci 23(4):1246-1253 
Brain KL, Cuprian AM, Williams DJ \& Cunnane TC (2003) The sources and sequestration of Ca(2+) contributing to neuroeffector $\mathrm{Ca}(2+)$ transients in the mouse vas deferens. J Physiol 553(2):627-635

Brain KL, Jackson VM, Trout SJ \& Cunnane TC (2002) Intermittent ATP release from nerve terminals elicits focal smooth muscle Ca2+ transients in mouse vas deferens. J Physiol 541(3):849-862

Bramich NJ \& Brading AF (1996) Electrical properties of smooth muscle in the guinea-pig urinary bladder. $J$ Physiol 492 (1):185-198

Brown EN \& Galligan JJ (2003) Muscarinic receptors couple to modulation of nicotinic ACh receptor desensitization in myenteric neurons. Am J Physiol Gastrointest Liver Physiol 285:G37-G44

Brüggmann D, Lips KS, Pfeil U, Haberberger RV \& Kummer W (2002) Multiple nicotinic acetylcholine $\alpha$-receptor subunits are expressed in the arterial system of the rat. Histochem Cell Biol 118:441-447

Calvert RC, Thompson CS, Khan MA, Mikhailidis DP, Morgan RJ \& Burnstock G (2001) Alterations in cholinergic and purinergic signaling in a model of the obstructed bladder. J Urol 166(4):1530-1533

Couturier S, Bertrand D, Matter JM, Hernandez MC, Bertrand S, Millar N, Valera S, Barkas T, Ballivet M (1990) A neuronal nicotinic acetylcholine receptor subunit $(\alpha 7)$ is developmentally regulated and forms a homooligomeric channel blocked by $\alpha$-BTX. Neuron 5(6):847-856

Creed KE, Loxley RA \& Phillips JK (2010) Functional expression of muscarinic and purinoceptors in the urinary bladder of male and female rats and guinea pigs. J Smooth Muscle Res 46(4):201-215

Csernoch L, Hunyadi J \& Kovács L (2000) Calcium release activated calcium entry in a human skin derived cell line. Exp Dermatol 9: 200-205

de Blasi A, Conn PJ, Pin J \& Nicoletti F (2001) Molecular determinants of metabotropic glutamate receptor signaling. Trends Pharmacol Sci 22(3):114-120

Dowdall MJ, Boyne AF \& Whittaker VP (1974) Adenosine triphosphate. A constituent of cholinergic synaptic vesicles. Biochem J 140(1):1-12

Dutton JL, Hansen MA, Balcar VJ, Barden JA \& Bennett MR (1999) Development of P2X receptor clusters on smooth muscle cells in relation to nerve varicosities in the rat urinary bladder. J Neurocytol 28(1):4-16 
Gabella G (1999) Structure of the intramural nerves of the rat bladder. J Neurocytol 28(8):615-637

Gabella G (1995) The structural relations between nerve fibres and muscle cells in the urinary bladder of the rat. $J$ Neurocytol 24(3):159-187

Grynkiewicz G, Poenie M \& Tsien RY (1985) A new generation of $\mathrm{Ca}^{2+}$ indicators with greatly improved fluorescence properties. J Biol Chem 260: 3440-3450

Hashitani H, Bramich NJ \& Hirst GD (2000) Mechanisms of excitatory neuromuscular transmission in the guineapig urinary bladder. J Physiol 524(2):565-579

Hirahara N, Ukimura O, Ushijima S, Yamada Y, Okihara K, Kawauchi A \& Miki T (2006) Four-dimensional ultrasonography for dynamic bladder shape visualization and analysis during voiding. J Ultrasound Med 25(3):307-313

Jenes A, Ruzsnavszky F, Szell EA, Varga A, Somogyi GT, Csernoch L \& Szigeti GP (2006) The role of the cholinergic and purinergic interaction in the contraction of the cultured human and rat urinary bladder smooth muscle cells. J Muscle Res Cell Motility 27:498

Jensen AA, Frolund B, Liljefors T \& Krogsgaard P (2005) Neuronal nicotinic acetylcholine receptors: Structural revelations, target identifications, and therapeutic inspirations. J Med Chem 48(15):4705-4745

Kasakov L \& Burnstock G (1982) The use of the slowly degradable analog, alpha, beta-methylene ATP, to produce desensitisation of the P2-purinoceptor: effect on non-adrenergic, non-cholinergic responses of the guineapig urinary bladder. Eur J Pharmacol 86(2):291-329

Kempsill FEJ, Covernton PJO, Whiting PJ, Connolly JG (1999) Agonist activation and a-bungarotoxin inhibition of wild type and mutant a7 nicotinic acetylcholine receptors. Eur J Pharmacol 383:347-359

Khakh BS, Fisher JA, Nashmi R, Bowser DN \& Lester HA (2005) An angstrom scale interaction between plasma membrane ATP-gated P2X 2 and $\alpha_{4} \beta_{2}$ nicotinic channels measured with fluorescence resonance energy transfer and total internal reflection fluorescence microscopy. J Neurosci 25(29):6911-6920

Khakh BS, Zhou X, Sydes J, Galligan JJ \& Lester HA (2000) State-dependent cross-inhibition between transmittergated cation channels. Nature 406:405-410 
Lai HH, Smith CP, Munoz A, Boone TB, Szigeti GP \& Somogyi GT (2008) Activation of cholinergic receptors blocks non-adrenergic non-cholinergic contractions in the rat urinary bladder. Brain Res Bull 77(6):420426

Lamont C, Vainorius E \& Wier WG (2003) Purinergic and adrenergic Ca2+ transients during neurogenic contractions of rat mesenteric small arteries. J Physiol 549(3):801-808

Lamont C \& Wier WG (2002) Evoked and spontaneous purinergic junctional Ca2+ transients (jCaTs) in rat small arteries. Circ Res 91(6):454-456

Lee HY, Bardini M \& Burnstock G (2000) Distribution of P2X receptors in the urinary bladder and the urethra of the rat. J Urol 163:2002-2007

Moldrich RX \& Beart PM (2003) Emerging signaling and receptor interactions mediated by metabotropic glutamate receptors. Curr Drug Targets CNS Neurol Disord 2(2):109-122

Nakazawa K (1994) ATP-activated current and its interaction with acetylcholine-activated current in rat sympathetic neurons. J Neurosci 14(2):740-750

Schneider T, Hein P, and Michel MC (2004) Signal transduction underlying carbachol-induced contraction of rat urinary bladder. I. Phospholipases and $\mathrm{Ca}^{2+}$ sources. J Pharmacol Exp Ther 308: 47-53

Searl TJ \& Silinsky EM (1998) Cross-talk between apparently independent receptors. J Physiol 513(3):629

Searl TJ, Redman RS \& Silinsky EM (1998) Mutual occlusion of P2X ATP receptors and nicotinic receptors on sympathetic neurons of the guinea-pig. J Physiol 510(3):783-791

Sokolova E, Nistri A \& Giniatullin R (2001) Negative cross talk between anionic GABA $A_{A}$ and cationic P2X ionotropic receptors of rat dorsal root ganglion neurons. J Neurosci 21(14):4958-4968

Somogyi GT \& de Groat WC (1992) Evidence for inhibitory nicotinic and facilitatory muscarinic receptors in cholinergic nerve terminals of the rat urinary bladder. J Auton Nerv Syst 37(2):89-97

Somogyi GT, Yokoyama T, Szell EA, Smith CP, de Groat WC, Huard J \& Chancellor MB (2002) Effect of cryoinjury on the contractile parameters of bladder strips: a model of impaired detrusor contractility. Brain Res Bull 59(1):23-28 
Studeny S, Torabi A \& Vizzard MA (2005) P2X2 and P2X3 receptor expression in postnatal and adult rat urinary bladder and lumbosacral spinal cord. Am J Physiol Regul Integr Comp Physiol 289(4):R1155-R1168

Szigeti GP, Somogyi GT, Csernoch L \& Széll EA (2005) Age-dependence of the spontaneous activity of the rat urinary bladder. J Muscle Res Cell Motility 26(1):23-29

Szigeti GP, Jenes A, Varga A, Szell EA, Somogy GT \& Csernoch L (2007) A possible role of the cholinergic and purinergic receptor interaction in the regulation of the urinary bladder function. J Muscle Res Cell Motility 28:467

Theobald RJ Jr \& de Groat WD (1989) The effects of purine nucleotides on transmission in vesical parasympathetic ganglia of the cat. J Auton Pharmacol 9(3):167-181

Zhou Z \& Galligan JJ (1998) Non-additive interaction between nicotinic cholinergic and P2X purinergic receptors in guinea-pig enteric neurons in culture. J Physiol 513(3):685-697 


\section{Legends to figures}

\section{Fig. 1}

Representative calcium transients evoked by repetitive application of ATP (180 $\mu M)$ on cultured smooth muscle cells from rat urinary bladder. (A) ATP-evoked $\mathrm{Ca}^{2+}$ transients in urinary bladder smooth muscle cells. (B, C, D) Pooled data from 7 similar experiments ( 7 cells from 7 different animals) where the parameters (amplitude (B), time constant $(\tau)$ of decay $(C)$ and maximum rate of rise $(D))$ of the $2^{\text {nd }}$ and $3^{\text {rd }}$ ATP-evoked transients were normalized to that of the first response in the given cell. None of the differences proved statistically significant $(p>0.3, p>0.5(B)$; $\mathrm{p}>0.1, \mathrm{p}>0.1(\mathrm{C}) ; \mathrm{p}>0.5, \mathrm{p}>0.3(\mathrm{D}))$.

\section{Fig. 2}

Representative calcium transients evoked by cholinergic and purinergic agonists in cultured and freshly isolated smooth muscle cells from adult rat urinary bladder.

The application of both ATP, carbachol(CCh)+ATP and nicotine(nic)+ATP resulted in a $\mathrm{Ca}^{2+}$ transient in rat smooth muscle cell from the dome (A) of the urinary bladder (ATP $180 \mu \mathrm{M}$, CCh $10 \mu \mathrm{M}$, nic $5 \mu \mathrm{M}, \mathrm{c}=16, \mathrm{n}=52$ ). In contrast, while carbachol prevented, nicotine did not interfere with the ATP-evoked $\mathrm{Ca}^{2+}$ transients in cultured (B) or freshly isolated $(\mathrm{C})$ rat smooth muscle cells from the base of the urinary bladder (carbachol: $\mathrm{c}=18$, $\mathrm{n}=57$, nicotine: $c=6, n=20$ in cultures, carbachol: $c=3, n=3$ freshly isolated). Here, and in subsequent figures, "c" represents the number of cultures, while " $n$ " represents the number of cells we obtained the results from. Markers show the onset of the 40s-long drug application.

\section{Fig. 3}

\section{Pharmacological characterization of the cross-inhibition.}

The muscarinic acetylcholine receptor blocker atropine (A: smooth muscle cell from the base, B: smooth muscle cell from the dome of the bladder; $1 \mu \mathrm{M}$ ) was unable to modify the purinergic-cholinergic interactions. The nicotinic acetylcholine receptor blocker $\alpha$-bungarotoxin did not interfere with the ATP-evoked signals in the cells isolated from the dome (D, $500 \mathrm{nM})$, but it prevented carbachol from inhibiting the ATP-evoked calcium transients in the cells isolated from the base $(\mathrm{C}, 500 \mathrm{nM})$. 


\section{Fig. 4}

Involvement of nicotinic signalling in the cross-inhibition.

The pooled data confirmed that the acetylcholine receptor agonist carbachol reduced the ATP-evoked $\mathrm{Ca}^{2+}$ transients in cultured rat smooth muscle cells from the base of the urinary bladder $(c=18, n=57, p<0.01)$. The acetylcholine receptor blocker atropine was unable to modify the purinergic-cholinergic interactions $(c=2, n=14, p<0.05)$, but the nicotinic acetylcholine receptor blocker $\alpha$-bungarotoxin prevented carbachol from inhibiting the ATP-evoked calcium transients in the cells isolated from the base $(c=3, n=20, p>0.05)$. Carbachol did not interfere with the ATPevoked signals in the cells isolated from the dome ( $c=16, n=52, p>0.05)$, and it was not influenced by either atropine $(\mathrm{c}=2, \mathrm{n}=10, \mathrm{p}>0.05)$ or $\alpha$-bungarotoxin $(\mathrm{c}=1, \mathrm{n}=3, \mathrm{p}>0.05) .{ }^{*},{ }^{*}$ indicate significant difference $\left({ }^{*} \mathrm{p}<0.01,{ }^{\#} \mathrm{p}<0.05\right)$ between control (ATP response) and test groups.

\section{Fig. 5}

Pharmacological characterization of the purinergic pathway.

Neither $\alpha, \beta$-methylene-ATP $(\operatorname{abm})(A ; 10 \mu \mathrm{M}, \mathrm{n}=6, \mathrm{c}=25)$, nor UTP $(\mathrm{B} ; 180 \mu \mathrm{M}, \mathrm{n}=5$, $\mathrm{c}=29)$ application could induce $\mathrm{Ca}^{2+}$ transients in cultured smooth muscle cells of the urinary bladder. Cells were obtained from the base and from the dome of the urinary bladders.

\section{Fig. 6}

\section{The immunostaining of $n A C h R \alpha 7$ subunits in rat urinary bladder.}

Results were obtained from cultured cells from rat urinary bladders (A), tissue sections (B) and muscle strips (C). The left column of panel A presents cultured cells from the base while the right column of panel A presents cultured cells from the dome of the urinary bladder. Green color shows smooth muscle cells stained with FITC conjugated secondary antibody. Blue color shows the nuclei of the cells stained with DAPI. Inserts in the right side of each image show negative controls. The brownish color (DAB) in the panel B presents cells which expressed nAChR $\alpha 7$. Left column of panel B shows section from the base, right column shows section from the dome of the bladder. 
Inserts in the corners show negative controls. Scale bar represents $25 \mu \mathrm{m}$ (A) or $250 \mu \mathrm{m}$ (B). The Western-blot confirmed $\mathrm{nAChR} \alpha 7$ protein expression in rat urinary bladder smooth muscle $(\mathrm{C})$, densitometry indicated a statistically more pronounced expression in the base, than in the dome $(\mathrm{D}, \mathrm{p}<0.05)$. The data are ratios of the signal at $56 \mathrm{kDa}(\mathrm{nAChR} \alpha 7$ protein) over the actin signal.

\section{Fig. 7}

$P 2 X_{2}$ receptors on urinary bladder smooth muscle cell cultures.

Cultured cells from the base of the urinary bladder are presented on the left side, cultured cells from the dome are on the right. Primary antibody against $\mathrm{P} 2 \mathrm{X}_{2}$ receptors (1:200), secondary antibody conjugated with FITC, nuclei stained with DAPI. Scale bar indicates $25 \mu \mathrm{m}$, inserts show negative controls. 